PENELITIAN

\title{
Perbedaan Elektrolit Plasma dan Tekanan Darah antara Preload Ringer Asetat Malat Dibandingkan dengan Ringer Laktat
}

\section{The Difference in Plasma Electrolyte and Blood Pressure Between Preload Ringer Acetate Malate Compared to Ringer Lactate}

\author{
Ifar Irianto Yudhowibowo $\square_{*}^{*}$, Doso Sutiyono**, Widya Istanto** \\ *Bagian Anestesiologi dan Terapi Intensif RSUD Muaro Jambi \\ **Bagian Anestesiologi dan Terapi Intensif Fakultas Kedokteran Universitas Diponegoro / RSUP Dr. Kariadi Semarang \\ $\triangle$ Korespondensi / correspondence: ifar.poenya@gmail.com
}

\section{ABSTRACT}

Background: Providing preload to prevent hypotension in spinal anesthesia may affect the balance of body's fluid.

Objectives: To observe the difference in change of plasma electrolyte concentrations $(\mathrm{Na}, \mathrm{K}, \mathrm{Cl})$ and blood pressure after spinal anesthesia between preload $20 \mathrm{cc} / \mathrm{kgBB}$ Ringer Acetate Malate (RAM) compared to Ringer's Lactate (RL).

Method: This is an experimental study phase II clinical trial randomized double-blind. The selection of samples obtained from consecutive random sampling with sample number 38. Group I $(n=19)$ received preload $20 \mathrm{cc} / \mathrm{kg}$ Ringer Acetate Malate and group II $(n=19)$ received preload $20 \mathrm{cc} / \mathrm{kg}$ Ringer's Lactate. Before granting preload, patient blood samples taken for examination electrolyte concentration ( $\mathrm{Na}, \mathrm{K}, \mathrm{Cl}$ ) plasma. After preload administration and 30 minutes after the blood samples were taken for examination electrolyte concentration and blood pressure measured. Statistical test with paired t-test test.

Result: The difference in Na concentration changes before preload and $\mathrm{Na}$ after preload and Na 30 minutes after preload between the group was significantly different. While the difference in Natrium concentration changes in preload after preload compared with $\mathrm{Na} 30$ minutes after preload between the group was not significantly different. Difference in $K$ concentration changes in $K$ before preload, $K$ after preload and $K 30$ minutes after preload between the group were not significantly different. Difference in $\mathrm{Cl}$ concentration changes $\mathrm{Cl}$ before 30 minutes after preload between the group significantly different. While the difference in $\mathrm{Cl}$ concentration changes of $\mathrm{Cl}$ before preload and $\mathrm{Cl}$ concentrations after 30 minutes post preload between the group was not significantly different. Systolic pressure significantly different $(p<0.005)$ between groups preload RAM and RL occurred between the 25th minute after spinal by the 30th minute after the spinal. As for the variable diastolic preassure significantly different $(p<0.005)$ between groups preload $R A M$ and $R L$ occurred between the 15th minute after spinal and 20th minute after spinal

Conclusion: Ringer Acetate Malate rises $\mathrm{Na}$ and $\mathrm{Cl}$ concentration in spinal anesthesia patient higher than Ringer Lactate immediately after loading, but no further electrolyte concentration difference were documented. Blood pressure changes 
were not significantly different between groups

Keywords: preload RAM, preload RL, electrolytes ( $\mathrm{Na}, \mathrm{K}, \mathrm{Cl}$ ), blood pressure

\section{ABSTRAK}

Latar belakang: Pemberian preload untuk mencegah hipotensi pada anestesi spinal dapat mempengaruhi keseimbangan cairan tubuh.

Tujuan: Untuk melihat perbedaan elektrolit plasma dan tekanan darah antara preload $R A M$ dibandingkan dengan $R L$.

Metode: Penelitian eksperimental uji klinis tahap II secara acak tersamar ganda. Pemilihan sampel secara Consecutive Random Sampling didapat jumlah sampel 38 orang. Kelompok I $(n=19)$ mendapat preload $20 \mathrm{cc} / \mathrm{kgBB}$ RAM dan kelompok II $(n=19)$ mendapat preload $20 \mathrm{cc} / \mathrm{kgbb}$ RL. Sebelum preload, diambil sampel darah untuk pemeriksaan konsentrasi elektrolit plasma. Setelah preload dan 30 menit setelah itu dilakukan pengambilan sampel darah untuk pemeriksaan konsentrasi elektrolit plasma. Pengukuran tekanan darah dilakukan sebelum anestesi spinal dan segera setelah anestesi spinal tiap 5 menit sampai 30 menit. Uji statistik dengan uji paired t-test.

Hasil: Selisih Na sebelum preload dan Na setelah preload dengan Na 30 menit setelah preload antara kelompok yang mendapat preload RAM dan RL berbeda bermakna. Sedangkan selisih Na setelah preload dengan Na 30 menit setelah preload berbeda tidak bermakna. Selisih K sebelum preload, K setelah preload dan 30 menit setelah preload dan $\mathrm{K} 30$ menit setelah preload berbeda tidak bermakna. Selisih $\mathrm{Cl}$ sebelum dan $\mathrm{Cl} 30$ menit setelah preload berbeda bermakna. Selisih $\mathrm{Cl}$ sebelum dan $\mathrm{Cl}$ setelah preload dan konsentrasi $\mathrm{Cl}$ setelah 30 menit preload berbeda tidak bermakna. Terdapat perbedaan tekanan sistolik yang bermakna antara kelompok preload RAM dan RL terjadi antara menit ke-25 sampai menit ke-30 setelah spinal. Sedangkan untuk variabel tekanan darah diastolik terdapat perbedaan yang bermakna antara kelompok preload $R A M$ dan $R L$ terjadi antara menit ke-15 sampai menit ke-20 setelah spinal.

Simpulan: RAM meningkatkan konsentrasi Na dan Cl lebih tinggi dibanding RL pada pasien dengan spinal anestesi segera setelah dilakukan loading, tetapi perbedaan konsentrasi elektrolit lebih jauh tidak ditemukan. Tidak ada perubahan tekanan darah yang bermakna diantara kedua kelompok.

Kata kunci : preload RAM, preload $R L$, elektrolit ( $\mathrm{Na}, \mathrm{K}, \mathrm{Cl})$, tekanan darah

\section{PENDAHULUAN}

Anestesi lokal semakin berkembang dan meluas pemakaiannya, mengingat berbagai keuntungan yang ditawarkan, diantaranya relatif murah, pengaruh sistemik minimal, menghasilkan analgesi adekuat dan kemampuan mencegah respon stress secara lebih sempurna. ${ }^{1} \mathrm{Hal}$ ini juga sebagai akibat dari 
berkembangnya obat-obatan anestesi lokal, peralatan dan pendekatan anatomi untuk blok saraf, bersamaan dengan pengetahuan yang semakin berkembang yang berhubungan dengan dosis, konsentrasi dan selanjutnya efek dari obat anestesi lokal yang digunakan. ${ }^{2}$

Pembagian anestesi lokal meliputi blok neuroaksial dan blok perifer. Blok neuroaksial meliputi spinal, epidural dan kaudal. Blok neuroaksial merupakan tindakan yang sering dikerjakan terutama spinal. ${ }^{3}$ Komplikasi hemodinamik paling penting yang berhubungan dengan anestesi lokal adalah hipotensi dan bradikardi. Insiden hipotensi pada beberapa penelitian berkisar 8 sampai 33\%. ${ }^{4}$ Preload cairan adalah tehnik sederhana untuk mengurangi hipotensi yang dipicu oleh blok neuroaksial., ${ }^{5,6}$ Pemberian volume dengan 10-20 cc/kg intravena pada pasien sehat akan mengkompensasi sebagian pada venous pooling setelah dilakukan blok neuroaksial. ${ }^{7}$

Pencegahan hipotensi dapat dilakukan dengan memberikan cairan kristaloid atau koloid (250 sampai 1000 cc) sebelum tindakan blok neuroaksial atau ada juga yang memberikan cairan kristaloid $20 \mathrm{cc} / \mathrm{kgbb}$ sebelum tindakan blok neuroaksial. ${ }^{6,8}$ Pemberian kristaloid sering dianjurkan untuk mengembalikan venous return dan cardiac output selama blok neuroaksial. ${ }^{9}$

Pemberian preload untuk mencegah hipotensi pada anestesi spinal dapat mempengaruhi keseimbangan cairan tubuh. ${ }^{10}$ Cairan tubuh terdiri dari air sebagai pelarut dan substansi terlarut sebagai zat terlarut. ${ }^{11}$ Di dalam zat terlarut tersebut mengandung elektrolit, diantaranya: $\mathrm{Na}, \mathrm{Ca}, \mathrm{Mg}, \mathrm{Cl}$, bikarbonat, fosfat, sulfat, asam oganik dan protein. Tetapi yang berpengaruh dalam menjaga keseimbangan cairan tubuh adalah $\mathrm{Na}$, $\mathrm{K}$ dan $\mathrm{Cl}$, karena elektrolit ini berfungsi antara lain adalah menjaga tekanan osmotik tubuh. ${ }^{12,13,14,15}$

Pemberian cairan dalam jumlah besar perlu dipilih cairan yang paling sedikit mempengaruhi osmolaritas plasma. Oleh karena itu diperlukan cairan isotonis. $^{10}$ Cairan kristaloid isotonik yang paling banyak digunakan adalah larutan Ringer (laktat atau asetat), RL mempunyai komposisi elektrolit mirip dengan cairan ekstraseluler. Larutan RAM adalah larutan elektrolit seimbang yang isotonis, larutan elektrolit penuh mengandung $140 \mathrm{mmol} / \mathrm{l} \mathrm{Na}$. Selain itu, konsentrasi $\mathrm{K}, \mathrm{Mg}$ dan $\mathrm{Ca}$ dari RAM mendekati konsentrasi dalam plasma manusia. Berbeda dari larutan RL, dimana Laktat terutama dimetabolisme di hati dan sebagian kecil pada ginjal, sementara Asetat Malat di metabolisme pada hampir semua jaringan tubuh terutama di otot. Metabolisme Asetat Malat juga didapatkan lebih cepat 3-4 kali dibandingkan Laktat. ${ }^{10,15,16,17}$

Wacana tersebut menyebabkan berkembangnya suatu pemikiran apakah menimbulkan perbedaan elektrolit $(\mathrm{Na}$, $\mathrm{K}, \mathrm{Cl}$ ) plasma dan tekanan darah pasca spinal anestesi antara preload 20cc/ kgBB RAM dibandingkan dengan 
preload 20cc/kgBB RL.

\section{METODE}

Penelitian ini merupakan penelitian eksperimental acak tersamar ganda, sampel dipilih dengan "Consecutive Random Sampling" dibagi menjadi dua kelompok yaitu kelompok I diberikan preload RAM $20 \mathrm{cc} / \mathrm{kgbb}$ dan kelompok II diberikan RL $20 \mathrm{cc} / \mathrm{kgbb}$ sebagai cairan preload anestesi spinal. Total sampel 38 penderita yang memenuhi kriteria inklusi yaitu: jenis kelamin laki - laki dan perempuan, umur 16 - 59 tahun, status fisik ASA I-II, menjalani operasi elektif dengan anestesi spinal, BMI normal, penderita yang bersedia diikutkan dalam penelitian. Dan kriteria eksklusi yaitu penderita yang mendapat pemberian cairan preload $>20 \mathrm{cc} / \mathrm{kgb}$, dan gangguan fungsi jantung.

Sebelum dilakukan preload, pasien diambil sampel darahnya sebanyak $3 \mathrm{cc}$ darah vena untuk pemeriksaan konsentrasi elektrolit plasma $(\mathrm{Na}, \mathrm{K}$, Cl) sebagai data dasar. Lima belas menit sebelum anestesi spinal, diberikan preload untuk masing-masing kelompok perlakuan, setelah dilakukan preload pasien diambil sampel darahnya sebanyak 3 cc darah vena untuk pemeriksaan konsentrasi elektrolit plasma ( $\mathrm{Na}, \mathrm{K}, \mathrm{Cl})$, tekanan darah sistolik (TDS) dan tekanan darah diastolik (TDD) diukur sebelum dilakukan anestesi spinal. Kemudian dilakukan anestesi spinal dengan jarum spinal $25 \mathrm{G}$ dengan 3 cc Bupivacain heavy $0,5 \%$, kecepatan injeksi $1 \mathrm{cc} / 5$ detik. Penderita diberikan oksigen 3 liter per menit. Segera setelah obat anestesi spinal disuntikkan, di ukur TDS dan TDD tiap 5 menit sampai 30 menit. Bila terjadi hipotensi, diterapi dengan injeksi efedrin intravena $10 \mathrm{mg}$ dan dapat diulang sampai hipotensi teratasi. Jumlah efedrin dicatat untuk diperbandingkan pada masing-masing kelompok.

Tiga puluh menit setelah pemberian preload dilakukan pengambilan sampel darah untuk pemeriksaan elektrolit plasma $(\mathrm{Na}, \mathrm{K}, \mathrm{Cl})$. Hasil pemeriksaan dibandingkan dengan data dasar.

\section{HASIL}

Karakteristik subyek penelitian diuji dengan person chi square dan didapatkan statistik bebeda tidak bemakna $(p>0,05)$

Pada analisis deskriptif konsentrasi $\mathrm{Na}$ terlihat kedua kelompok pasien mengalami penurunan konsentrasi $\mathrm{Na}$ setelah diberi preload. Namun kelompok pasien yang mendapat preload RL mengalami penurunan konsentrasi $\mathrm{Na}$ yang lebih banyak daripada kelompok pasien yang mendapat preload RAM.

Tabel 1 menunjukkan konsentrasi $\mathrm{Na}$ kelompok RAM sebelum dan setelah 30 menit preload didapatkan nilai $\mathrm{p}<0,05$ sehingga disimpulkan berbeda bermakna, sedangkan konsentrasi $\mathrm{Na}$ sebelum preload dengan $\mathrm{Na}$ setelah preload dan konsentrasi $\mathrm{Na}$ setelah preload dengan $\mathrm{Na} 30$ menit setelah preload didapatkan nilai $\mathrm{p}>0,05$ 
sehingga disimpulkan berbeda tidak bermakna. Pada kelompok RL konsentrasi Na sebelum preload dengan $\mathrm{Na}$ setelah preload, Na sebelum dengan $\mathrm{Na} 30$ menit setelah preload dan $\mathrm{Na}$ setelah preload dengan $\mathrm{Na} 30$ menit setelah preload didapatkan semua nilai $\mathrm{p}<0,05$ sehingga disimpulkan berbeda bermakna.

Dari tabel 2 menunjukkan selisih perubahan konsentrasi $\mathrm{Na}$ sebelum dengan $\mathrm{Na}$ setelah preload dan $\mathrm{Na}$ sebelum preload dengan $\mathrm{Na} 30$ menit setelah preload antara kelompok yang mendapat preload RAM dan kelompok yang mendapat preload RL nilai $\mathrm{p}<0,05$ sehingga disimpulkan berbeda bermakna. Sedangkan selisih perubahan konsentrasi $\mathrm{Na}$ setelah preload dengan $\mathrm{Na} 30$ menit setelah preload antara kelompok yang mendapat preload RL dan kelompok yang mendapat preload RAM nilai $\mathrm{p}>0,05$ sehingga disimpulkan berbeda tidak bermakna.

Pada analisis deskriptif konsentrasi K terlihat kedua kelompok pasien mengalami penurunan konsentrasi $\mathrm{K}$ setelah diberi preload. Namun kelompok pasien yang mendapat preload RAM mengalami kenaikan konsentrasi $\mathrm{K}$ kembali 30 menit setelah preload.

Dari tabel 3, pada kelompok RAM konsentrasi $\mathrm{K}$ sebelum dengan $\mathrm{K}$ setelah preload dan $\mathrm{K}$ sebelum dengan $\mathrm{K} 30$ menit setelah preload didapatkan nilai $\mathrm{p}<0,05$ sehingga dapat disimpulkan berbeda bermakna sedangkan pada konsentrasi $\mathrm{K}$ setelah preload dengan $\mathrm{K}$ 30 menit setelah preload didapatkan nilai $p>0,05$ sehingga dapat disimpulkan

Tabel 1. Hasil uji beda berpasangan konsentrasi $\mathrm{Na}$

\begin{tabular}{lcc}
\hline \multicolumn{1}{c}{ Variable } & \multicolumn{2}{c}{ Infus } \\
\cline { 2 - 3 } & RAM (p value) & RL (p value) \\
\hline Na sebelum - setelah preload & $0,170^{¥}$ & $0,000^{¥}$ \\
\hline Na sebelum - Na 30 mnt setelah preload & $0,017^{¥}$ & $0,000^{¥}$ \\
\hline Na setelah - 30 mnt setelah preload & $0,097^{¥}$ & $0,003^{¥}$ \\
\hline
\end{tabular}

Keterangan :

${ }^{¥}$ Wilcoxon test

Tabel 2. Hasil uji beda tidak berpasangan selisih konsentrasi $\mathrm{Na}$

\begin{tabular}{lccc}
\hline \multicolumn{1}{c}{ Variable } & \multicolumn{2}{c}{ Infus } & \multirow{2}{*}{ p } \\
\cline { 2 - 3 } & RAM & RL & \\
\hline Selisih Na sebelum - setelah preload & $-0,26 \pm 1,050$ & $-1,27 \pm 0,753$ & $0,001^{\&}$ \\
\hline Selisih Na sebelum -30 mnt setelah preload & $-0,61 \pm 1,336$ & $-1,82 \pm 0,919$ & $0,002^{\&}$ \\
\hline Selisih Na setelah -30 mnt setelah preload & $-0,35 \pm 0,779$ & $-0,54 \pm 0,581$ & $0,368^{\#}$ \\
\hline
\end{tabular}

Keterangan :

\& Mann Whitney Test

\# Independent $\mathrm{t}$ test 
Tabel 3. Hasil uji beda berpasangan konsentrasi K

\begin{tabular}{ccc}
\hline \multirow{2}{*}{ Variable } & \multicolumn{2}{c}{ Infus } \\
\cline { 2 - 3 } & RAM (p value) & RL (p value) \\
\hline K sebelum preload- setelah preload & $0,003^{\ddagger}$ & $0,153^{¥}$ \\
\hline K sebelum preload-30 mnt setelah preload & $0,045^{¥}$ & $0,117^{¥}$ \\
\hline K setelah preload - 30 mnt setelah preload & $0,295^{¥}$ & $0,794^{¥}$ \\
\hline
\end{tabular}

Keterangan :

Paired t test

$¥$ Wilcoxon test

berbeda tidak bermakna. Pada terlihat kedua kelompok pasien kelompok RL konsentrasi $\mathrm{K}$ sebelum mengalami kenaikan konsentrasi $\mathrm{Cl}$ dengan $\mathrm{K}$ setelah preload, $\mathrm{K}$ sebelum setelah diberi preload. Namun kelompok dengan K 30 menit setelah preload dan pasien yang mendapat preload RAM $\mathrm{K}$ setelah preload dengan $\mathrm{K} 30$ menit setelah preload didapatkan nilai $\mathrm{p}>$ 0,05 sehingga dapat disimpulkan berbeda bermakna.

Dari tabel 4 didapatkan selisih perubahan konsentrasi $\mathrm{K}$ sebelum dengan $\mathrm{K}$ setelah preload, $\mathrm{K}$ sebelum dengan $\mathrm{K} 30$ menit setelah preload dan $\mathrm{K}$ setelah dengan $\mathrm{K} 30$ menit setelah preload antara kelompok yang mendapat preload RL dan kelompok yang mendapat preload RAM nilai $\mathrm{p}>0,05$ sehingga disimpulkan berbeda tidak bermakna.

Pada analisis deskriptif konsentrasi $\mathrm{Cl}$ mengalami kenaikan konsentrasi $\mathrm{Cl}$ yang lebih tinggi daripada kelompok pasien yang mendapat preload RL.

Dari tabel 5 didapatkan pada kelompok RAM pada konsentrasi $\mathrm{Cl}$ sebelum preload dengan $\mathrm{Cl}$ setelah preload dan $\mathrm{Cl}$ sebelum dengan $\mathrm{Cl} 30$ setelah menit preload didapatkan nilai $\mathrm{p}<0,05$ sehingga disimpulkan berbeda bermakna, sedangkan pada konsentrasi $\mathrm{Cl}$ setelah preload dengan $\mathrm{Cl} 30$ menit setelah preload didapatkan nilai $\mathrm{p}>0,05$ sehingga disimpulkan berbeda tidak bermakna. Pada kelompok RL konsentrasi $\mathrm{Cl}$ sebelum dengan $\mathrm{Cl}$ setelah preload, $\mathrm{Cl}$ sebelum preload

Tabel 4. Hasil uji beda tidak berpasangan selisih konsentrasi K

\begin{tabular}{lccc}
\hline \multicolumn{1}{c}{ Variable } & \multicolumn{2}{c}{ Infus } & p \\
\cline { 2 - 3 } & RAM & RL & \\
\hline Selisih K sebelum - K setelah preload & $-0,27 \pm 0,341$ & $-0,10 \pm 0,279$ & $0,112^{\#}$ \\
\hline Selisih K sebelum - K 30 mnt stlh preload & $-0,17 \pm 0,340$ & $-0,12 \pm 0,340$ & $0,646^{\#}$ \\
\hline Selisih K stlh - K 30 mnt stlh preload & $0,10 \pm 0,353$ & $-0,18 \pm 0,214$ & $0,237^{\#}$ \\
\hline
\end{tabular}

Keterangan :

\# Independent $t$ test 
Tabel 5. Hasil uji beda berpasangan konsentrasi $\mathrm{Cl}$

\begin{tabular}{|c|c|c|}
\hline \multirow{2}{*}{ Variable } & \multicolumn{2}{|c|}{ Infus } \\
\hline & RAM (p value) & RL (p value) \\
\hline $\mathrm{Cl}$ sebelum $-\mathrm{Cl}$ stlh preload & $0,000^{¥}$ & $0,144^{\ddagger}$ \\
\hline $\mathrm{Cl}$ sebelum $-\mathrm{Cl} 30 \mathrm{mnt}$ stlh preload & $0,000^{¥}$ & $0,162^{¥}$ \\
\hline Cl stlh - Cl 30 mnt stlh preload & $0,308^{¥}$ & $0,452^{¥}$ \\
\hline
\end{tabular}

Keterangan :

* Paired $t$ test

${ }^{¥}$ Wilcoxon test

dengan $\mathrm{Cl} 30$ menit setelah preload dan $\mathrm{Cl}$ setelah dengan $\mathrm{Cl} 30$ menit setelah preload didapatkan semua nilai $\mathrm{p}>0,05$ sehingga disimpulkan berbeda tidak bermakna.

Dari tabel 6 didapatkan selisih perubahan konsentrasi $\mathrm{Cl}$ sebelum dengan $\mathrm{Cl} 30$ menit setelah preload antara kelompok yang mendapat preload RL dan kelompok yang mendapat preload RAM nilai $\mathrm{p}<0,05$ sehingga disimpulkan berbeda bermakna. Sedangkan selisih perubahan konsentrasi $\mathrm{Cl}$ sebelum dengan $\mathrm{Cl}$ setelah preload dan konsentrasi $\mathrm{Cl}$ setelah dengan $\mathrm{Cl} 30$ menit setelah preload antara kelompok yang mendapat preload RL dan kelompok yang mendapat preload RAM nilai $\mathrm{p}>0,05$ sehingga disimpulkan berbeda tidak bermakna.

Pada pengamatan tekanan darah didapatkan perubahan TDS pada setiap waktu pengukuran antara kelompok RAM dan kelompok RL. Pada kedua Kelompok memperlihatkan penurunan TDS setelah menit ke-0 spinal. Namun pada kelompok RAM terjadi kenaikan TDS setelah menit ke-20 spinal, sedangkan pada kelompok RL terjadi kenaikan setelah menit ke-15 spinal.

Perubahan TDD pada kedua kelompok memperlihatkan penurunan TDD setelah menit ke-0 spinal. Namun setelah itu, pada kelompok RAM terjadi naik turun TDD, dimana terjadi kenaikan setelah menit ke-5 dan ke-20 spinal kemudian

Tabel 6. Hasil uji beda tidak berpasangan selisih konsentrasi $\mathrm{Cl}$

\begin{tabular}{lccc}
\hline \multicolumn{1}{c}{ Variable } & \multicolumn{2}{c}{ Infus } & p \\
\cline { 2 - 3 } & RAM & RL & \\
\hline Selisih Cl sebelum - Cl stlh preload & $0,80 \pm 0,734$ & $0,30 \pm 0,856$ & $0,061^{\#}$ \\
\hline Selisih Cl sebelum - Cl 30 mnt stlh preload & $0,94 \pm 0,926$ & $0,37 \pm 0,938$ & $0,040^{\&}$ \\
\hline Selisih Cl stlh - Cl 30 mnt stlh preload & $0,14 \pm 0,568$ & $0,07 \pm 0,467$ & $0,931^{\&}$ \\
\hline & & & \\
Keterangan : & & & \\
\# Independent t test & & & \\
\& Mann Whitney Test & & &
\end{tabular}


terjadi penurunan TDD setelah menit ke -10 dan ke-25 spinal. Pada kelompok RL terjadi kenaikan setelah menit ke-15 spinal.

Data yang didapat menunjukan bahwa pada kelompok RAM hanya TDS menit ke-20 setelah spinal didapatkan nilai $\mathrm{p}<$ 0,05 sehingga dapat disimpulkan berbeda bermakna, sedangkan pada menit-menit lainnya didapatkan nilai $\mathrm{p}>0,05$ sehingga disimpulkan berbeda tidak bermakna. Pada TDD didapatkan nilai $p>0,05$ sehingga disimpulkan berbeda tidak bermakna perubahan TDD setiap menitnya setelah spinal.

Untuk variabel TDS terdapat perbedaan yang bermakna $(\mathrm{p}<0,005)$ antara kelompok preload RAM dan kelompok preload RL terjadi antara menit ke-25 setelah spinal dengan menit ke-30 setelah spinal. Sedangkan untuk variabel TDD terdapat perbedaan yang bermakna $(p<0,005)$ antara kelompok preload RAM dan kelompok preload RL terjadi antara menit ke-15 setelah spinal dengan menit ke-20 setelah spinal.

\section{PEMBAHASAN}

Dari penelitian didapatkan data perubahan konsentrasi $\mathrm{Na}$ pada RAM dan RL pada sebelum preload, setelah preload dan 30 menit setelah preload mengalami penurunan, hal ini disebabkan karena pemberian preload sehingga terjadi pengenceran zat terlarut didalam plasma sehingga terjadi penurunan konsentrasi Na. Pada kelompok RL penurunan konsentrasi $\mathrm{Na}$ sebelum preload dengan $\mathrm{Na}$ setelah preload, Na sebelum preload dengan $\mathrm{Na}$ 30 menit setelah preload dan Na setelah preload dengan $\mathrm{Na} 30$ menit setelah preload semuanya didapatkan nilai $\mathrm{p}<0,05$ sehingga dapat disimpulkan berbeda bermakna, sedangkan pada kelompok RAM penurunan konsentrasi $\mathrm{Na}$ sebelum preload dengan $\mathrm{Na}$ setelah preload dan $\mathrm{Na}$ setelah preload dengan $\mathrm{Na} 30$ menit setelah preload didapatkan nilai $\mathrm{p}>0,05$ sehingga dapat disimpulkan berbeda tidak bermakna. Hal ini disebabkan karena konsentrasi Na pada cairan RAM $140 \mathrm{mmol} / \mathrm{L}$ lebih besar daripada cairan RL $130 \quad \mathrm{mmol} / \mathrm{L}$ sehingga penurunan konsentrasi $\mathrm{Na}$ lebih berbeda bermakna pada kelompok preload RL. Pada kelompok RAM penurunan konsentrasi $\mathrm{Na}$ sebelum preload dengan $\mathrm{Na} 30$ menit setelah preload didapatkan nilai $\mathrm{p}<0,05$ sehingga dapat disimpulkan berbeda bermakna. Hal ini disebabkan penurunan konsentrasi $\mathrm{Na}$ lebih besar pada 30 menit setelah preload dibandingkan pada setelah preload kemungkinan karena sudah mulai terjadi keseimbangan $\mathrm{Na}$ sehingga penurunan konsentrasi $\mathrm{Na}$ sebelum preload dengan $\mathrm{Na} 30$ menit setelah preload didapatkan berbeda bermakna.

Data hasil uji beda tidak berpasangan selisih $\mathrm{Na}$, didapatkan pada selisih $\mathrm{Na}$ sebelum dengan $\mathrm{Na}$ setelah preload dan selisih Na sebelum dengan Na 30 menit setelah preload pada kelompok RAM terhadap RL didapatkan nilai $\mathrm{p}<0,05$ 
sehingga dapat disimpulkan berbeda bermakna, sedangkan selisih konsentrasi $\mathrm{Na}$ setelah preload dengan $\mathrm{Na} 30$ menit setelah preload pada kelompok infus RAM terhadap RL didapatkan nilai $\mathrm{p}>0,05$ sehingga dapat disimpulkan berbeda tidak bermakna. Hal ini disebabkan penurunan konsentrasi $\mathrm{Na}$ sebelum dengan setelah preload dan Na sebelum preload dengan $\mathrm{Na} 30$ menit setelah preload pada kelompok RL lebih besar daripada kelompok RAM sehingga selisih $\mathrm{Na}$ sebelum dengan setelah preload dan selisih Na sebelum preload dengan 30 menit setelah preload didapatkan berbeda bermakna.

Hal ini berbeda dengan penelitian yang dilakukan oleh Hartanto dkk, dimana didapatkan kenaikan konsentrasi $\mathrm{Na}$ baik pada kelompok RAM maupun kelompok RL, dan kenaikan ini didapatkan bermakna secara statistik. Pada selisih perubahan konsentrasi $\mathrm{Na}$ didapatkan tidak berbeda bermakna. ${ }^{10}$

Dari tabel 3 dan 4 didapatkan data perubahan konsentrasi $\mathrm{K}$ pada kelompok RAM dan RL pada sebelum preload, setelah preload dan 30 menit setelah preload mengalami penurunan hal ini disebabkan karena pemberian preload sehingga terjadi pengenceran zat terlarut didalam plasma sehingga terjadi penurunan konsentrasi K. Pada kelompok RL, konsentrasi $\mathrm{K}$ sebelum preload dengan $\mathrm{K}$ setelah preload, $\mathrm{K}$ sebelum preload dengan K 30 menit setelah preload dan $\mathrm{K}$ setelah preload dengan K 30 menit setelah preload semuanya didapatkan nilai $p>0,05$ sehingga dapat disimpulkan berbeda tidak bermakna. Sedangkan pada kelompok RAM penurunan konsentrasi $\mathrm{K}$ sebelum preload dengan $\mathrm{K}$ setelah preload dan $\mathrm{K}$ pra preload dengan $\mathrm{K} 30$ menit setelah preload didapatkan nilai $\mathrm{p}<0,05$ sehingga dapat disimpulkan berbeda bermakna. Hal ini disebabkan karena konsentrasi $\mathrm{K}$ pada cairan RL (5 mmol/L) lebih besar daripada cairan RAM (4 mmol/L) sehingga pada kelompok RL penurunan konsentrasi $\mathrm{K}$ sebelum preload dengan $\mathrm{K}$ setelah preload, $\mathrm{K}$ sebelum preload dengan $\mathrm{K}$ 30 menit setelah preload dan $\mathrm{K}$ setelah preload dengan K 30 menit setelah preload lebih sedikit daripada kelompok RAM. Pada kelompok RAM konsentrasi $\mathrm{K}$ setelah preload dengan 30 menit setelah preload didapatkan nilai $\mathrm{p}>0,05$ sehingga dapat disimpulkan berbeda tidak bermakna. Hal ini disebabkan karena konsentrasi K 30 menit setelah preload mengalami kenaikan, mungkin disebabkan sudah mulai terjadi keseimbangan konsentrasi $\mathrm{K}$ dalam plasma, sehingga konsentrasi $\mathrm{K}$ setelah preload dengan 30 menit setelah preload didapatkan berbeda tidak bermakna.

Dari data hasil uji beda tidak berpasangan selisih $\mathrm{K}$, didapatkan pada selisih $\mathrm{K}$ sebelum preload dengan $\mathrm{K}$ setelah preload, selisih $\mathrm{K}$ sebelum preload dengan K 30 menit setelah preload dan selisih $\mathrm{K}$ setelah preload dengan K 30 menit setelah preload pada kelompok RAM terhadap RL 
didapatkan nilai $\mathrm{p}>0,05$ sehingga dapat disimpulkan berbeda tidak bermakna. Hal ini disebabkan karena konsentrasi $\mathrm{K}$ pada cairan RAM (4 mmol/L) dan RL (5 mmol/L) jumlahnya tidak berbeda jauh sehingga selisih konsentrasi $\mathrm{K}$ didapatkan tidak berbeda bermakna.

Dari data perubahan konsentrasi $\mathrm{Cl}$ RAM dan RL didapatkan pada sebelum preload, setelah preload dan 30 menit setelah preload mengalami kenaikan, hal ini disebabkan konsentrasi $\mathrm{Cl}$ pada cairan RAM dan cairan RL lebih besar daripada konsentrasi $\mathrm{Cl}$ dalam plasma pada sampel, sehingga baik pada kelompok RAM dan kelompok RL sama-sama terjadi kenaikan konsentrasi Cl. Pada kelompok RAM, konsentrasi $\mathrm{Cl}$ sebelum preload dengan $\mathrm{Cl}$ setelah preload dan $\mathrm{Cl}$ sebelum preload dengan Cl 30 menit preload didapatkan kenaikan yang berbeda bermakna sedangkan pada kelompok RL konsentrasi $\mathrm{Cl}$ sebelum preload dengan $\mathrm{Cl}$ setelah preload, $\mathrm{Cl}$ sebelum preload dengan $\mathrm{Cl} 30$ menit sebelum preload dan $\mathrm{Cl}$ setelah preload dengan $\mathrm{Cl} 30$ menit setelah preload semuanya didapatkan kenaikan yang berbeda tidak bermakna. Hal ini disebabkan konsentrasi $\mathrm{Cl}$ pada cairan RAM (127 $\mathrm{mmol} / \mathrm{L})$ lebih besar daripada konsentrasi $\mathrm{Cl}$ pada cairan RL (112 $\mathrm{mmol} / \mathrm{L}$ ). Sehingga kenaikan konsentrasi $\mathrm{Cl}$ pada kelompok RAM lebih berbeda bermakna. Pada kelompok RAM konsentrasi $\mathrm{Cl}$ setelah preload dengan 30 menit setelah preload didapatkan berbeda tidak bermakna, hal ini mungkin disebabkan sudah mulai terjadi keseimbangan konsentrasi $\mathrm{Cl}$ dalam plasma.

Dari data hasil uji beda tidak berpasangan selisih $\mathrm{Cl}$, didapatkan pada selisih $\mathrm{Cl}$ sebelum preload dengan $\mathrm{Cl} 30$ menit setelah preload pada kelompok RAM terhadap RL didapatkan nilai $\mathrm{p}<0,05$ sehingga dapat disimpulkan berbeda bermakna. Sedangkan pada selisih $\mathrm{Cl}$ sebelum preload dengan $\mathrm{Cl}$ setelah preload dan selisih $\mathrm{Cl}$ setelah preload dengan $\mathrm{Cl} 30$ menit setelah preload pada kelompok Infus RAM terhadap RL didapatkan nilai $p>0,05$ sehingga dapat disimpulkan berbeda tidak bermakna. Hal ini disebabkan konsentrasi $\mathrm{Cl}$ pada cairan RAM (127 $\mathrm{mmol} / \mathrm{L})$ lebih besar daripada konsentrasi $\mathrm{Cl}$ pada cairan RL (112 mmol/L), hal ini menyebabkan kenaikan konsentrasi $\mathrm{Cl} 30$ menit setelah preload pada kelompok RAM lebih besar daripada kelompok RL, sehingga selisih Cl sebelum dengan 30 menit setelah preload lebih besar daripada selisih $\mathrm{Cl}$ sebelum dengan setelah preload dan $\mathrm{Cl}$ setelah preload dengan 30 menit setelah preload. Sehingga selisih $\mathrm{Cl}$ sebelum preload dengan $\mathrm{Cl} 30$ menit setelah preload pada kelompok Infus RAM terhadap RL berbeda bermakna.

Pada penelitian ini juga dinilai perubahan hemodinamik yang meliputi TDS dan TDD pada kelompok pertama yang diberikan preload $20 \mathrm{cc} / \mathrm{kgBB}$ RAM dan kelompok kedua yang diberikan preload $20 \mathrm{cc} / \mathrm{kgBB} \quad \mathrm{RL}$ 
sebelum anestesi spinal

Secara statistik TDS dan TDD pada kelompok yang mendapatkan preload $20 \mathrm{cc} / \mathrm{kgBB}$ RAM tidak mengalami perubahan yang bermakna setelah anestesi spinal. Hal ini disebabkan oleh karena preload RAM memberikan volume intravaskuler tambahan untuk mempertahankan venous return dan curah jantung, sehingga dapat mempertahankan tekanan darah setelah anestesi spinal dilakukan. Mulai menit ke-20 terjadi penurunan TDS yang bermakna. Penurunan itu disebabkan karena RAM sudah mulai berdifusi ke ruang interstitial, sehingga tidak dapat mempertahankan venous return dan curah jantung yang menyebabkan tekanan darah turun, namun setelahnya perubahan tekanan darah menjadi stabil kembali karena adanya peran efedrin untuk membantu menstabilkan tekanan darah. Hasil penelitian ini mendukung penelitian sebelumnya yang dilakukan oleh Tjokrowinoto yang membandingkan perubahan tekanan darah antara pemberian preload RAM dengan tanpa preload dimana didapatkan perbedaan yang tidak bermakna pada TDS dan TDD antara sebelum dan sesudah anestesi spinal. ${ }^{18}$

Secara statistik kelompok yang mendapatkan preload RL, didapatkan penurunan yang bermakna $(p<0,05)$ pada TDS setelah spinal sedangkan pada TDD didapatkan penurunan yang tidak bermakna $(p>0,05)$ setelah spinal. Hal ini disebabkan oleh menurunnya resistensi vaskuler sistemik dan curah jantung karena pengaruh blok simpatis saat anestesi spinal sehingga menyebabkan penurunan tekanan darah. Mulai menit ke-15 terjadi penurunan TDS yang bermakna. Penurunan itu disebabkan karena RL sudah mulai berdifusi ke ruang interstitial, sehingga tidak dapat mempertahankan venous return dan curah jantung yang menyebabkan tekanan darah turun. Hasil penelitian ini tidak sesuai dengan penelitian sebelumnya yang dilakukan oleh Sari (2012) yang membandingkan perubahan tekanan darah antara pemberian preload RL dengan tanpa preload dimana didapatkan perbedaan yang tidak bermakna pada TDS dan TDD antara sebelum dan sesudah anestesi spinal. ${ }^{19}$

Hasil penelitian ini juga menunjukan selisih perubahan/penurunan TDS dan TDD antara kelompok yang mendapatkan preload RAM dengan yang mendapatkan preload RL. Perubahan TDS yang bermakna terjadi pada menit ke-25 dengan menit ke-30 setelah spinal. Perubahan TDD yang bermakna terjadi pada menit ke-15 dengan menit ke-20 setelah spinal. Hal ini menunjukkan tidak adanya perbedaan tekanan darah yang bermakna antara kelompok yang mendapat preload RAM dengan kelompok yang mendapat preload RL. Bila dibandingkan dengan penelitian yang dilakukan oleh Tjokrowinoto yang membandingkan perubahan tekanan darah antara pemberian preload RAM dengan tanpa preload didapatkan perubahan TDS 
yang bermakna terjadi antara sebelum preload dengan menit ke-0 setelah spinal dan antara menit ke-0 sampai menit ke-3 setelah spinal. Perubahan TDD yang bermakna terjadi pada menit antara ke-12 dengan menit ke-15 setelah spinal. $^{18}$ Sedangkan pada penelitian yang dilakukan oleh Sari (2012) yang membandingkan perubahan tekanan darah antara pemberian preload RL dengan tanpa preload didapatkan perubahan TDS terdapat perbedaan yang bermakna antara pre preload dengan menit ke-0 setelah spinal. Sedangkan untuk perubahan TDD tidak terdapat perbedaan bermakna. ${ }^{19}$

\section{SIMPULAN}

Terdapat perbedaan bermakna konsentrasi Na pada selisih Na sebelum preload dengan $\mathrm{Na}$ setelah preload dan $\mathrm{Na}$ sebelum preload dengan $\mathrm{Na} 30$ menit setelah preload. Tidak terbukti terdapat perbedaan bermakna konsentrasi $\mathrm{Na}$ pada selisih $\mathrm{Na}$ setelah preload dengan $\mathrm{Na} 30$ menit setelah preload. Tidak terbukti terdapat perbedaan bermakna konsentrasi $\mathrm{K}$.

Terbukti terdapat perbedaan bermakna konsentrasi $\mathrm{Cl}$ pada selisih $\mathrm{Cl}$ sebelum preload dengan $\mathrm{Cl} 30$ menit setelah preload. Tidak terdapat perbedaan bermakna konsentrasi $\mathrm{Cl}$ pada selisih $\mathrm{Cl}$ sebelum preload dengan setelah preload dan $\mathrm{Cl}$ setelah preload dengan $\mathrm{Cl} \quad 30$ menit setelah preload.

Tidak terdapat perbedaan tekanan darah yang bermakna antara pasien yang mendapat preload $20 \mathrm{cc} / \mathrm{kgBB}$ RAM dengan yang mendapat preload $20 \mathrm{cc} /$ kgBB RL pasca anestesi spinal.

\section{DAFTAR PUSTAKA}

1. Marwoto, Primatika A D. Anestesi lokal/ regional. Dalam: Soenarjo, Jatmiko H D, editor. Anestesiologi. Semarang: IDSAI cabang Jawa Tengah;2010.p.309-18.

2. Aitkenhead A R, Rowbotham D J, Smith G, editor. Textbook of aneaesthesia: lokal anaesthetic techniques. 4th ed. Philadelphia: Elsevier science limited; 2002. p. 555.

3. Latief S A, Suryadi K A, Daclan M R. Analgesia regional. Dalam: Latief S A, Suryadi K A, Daclan M R, editor. Petunjuk praktis anestesiologi. Edisi ke-2. Jakarta: Bagian anestesiologi dan terapi intensif FK UI; 2009. p. 105-7.

4. Liguori G A. Hemodynamic complications Dalam: Neal J M, Rathmell J P, editor. Complications in regional anesthesia and pain medicine. Philadelphia: Elsevier Inc; 2007. p. 43-4,50.

5. Muzlifah K B, Choy Y C. Comparison between preloading with $10 \mathrm{ml} / \mathrm{kg}$ and 20 $\mathrm{ml} / \mathrm{kg}$ of ringer's lactate in preventing hypotension during spinal anaesthesia for caesarean section. Med J Malaysia. 2009; 64(2): 114.

6. Duke J. Spinal anesthesia. Dalam: Duke J, editor. Anesthesia secrets. 4th ed. Philadelphia: Mosby Inc; 2011. p. 452.

7. Rosenquist Richard, Vrooman Bruce. The Pain management. Dalam: Morgan G E, Mikhail M S, Murray M J, editor. Clinical anesthesiology: 4th ed. New York: Mc Graw-Hill companies; 2006. p. 297-8.

8. Sapola J A L. Complications of regional anesthesia. in: Sapola J A L, editor. Anesthesia oral board review. Cambridge: Cambridge university press; 2010. p. 201.

9. Bernards $C$ M. Epidural and spinal anesthesia. in: Barash P G, Cullen B F, Stoelting R K, editor. Clinical anesthesia. 4th ed. Philadelphia: Lippincott williams and wilkins publishers; 2001. p. 519-20.

10. Hartanto R V. Perbedaan perubahan konsentrasi natrium plasma antara preload 20 $\mathrm{cc} / \mathrm{kgbb}$ ringer laktat dibandingkan dengan preload $20 \mathrm{cc} / \mathrm{kgbb}$ ringer asetat malat. S.Ked [thesis]. Semarang: Univer- 
sitas Diponegoro; 2012. p. 2, 72.

11. Horne M M, Swearingen P L. Ikhtisar keseimbangan cairan dan elektrolt. Dalam: Asih Y, editor. Keseimbangan cairan, elektrolit dan asam basa. Edisi ke -2. Jakarta: EGC; 2000. p. 1-3.

12. Mulyono I, Sunatrio S. Prinsip-prinsip dasar cairan tubuh. Dalam: Harijanto E, editor. Paduan tatalaksana terapi cairan perioperatif. Jakarta: PP IDSAI; 2010. p. 7,14 .

13. Irawan M A. Cairan tubuh, elektrolit dan mineral. Sports science brief. 2007;1(1): $1-5$

14. Zander R. Infusion fluid: why should they be balanced solutions?. EJHP Practice. $2006 ; 12(6)$ : 60 .

15. Hartanto W W. Terapi cairan dan elektrolit perioperatif. [tinjauan pustaka]. Bandung: universitas Padjadjaran; 2007. p. 5-6, 16-7, 20-1.

16. Prough D S, Svensen C H. Crystalloid solutions. in: Hahn R G, Prough D S, Svensen C, editor. Perioperative fluid therapy. New York: Informa healthcare USA Inc; 2007. p. 143.

17. Ringer asetat (asering) mencegah hipotermia pesectiorioperatif. Majalah farmacia. 2006; 5(9): 34.

18. Tjokrowinoto S. Perbedaan tekanan darah pasca anestesi spinal dengan pemberian preload dan tanpa pemberian preload $20 \mathrm{cc} / \mathrm{kgbb}$ ringer asetat malat. S.Ked [thesis]. Semarang: Universitas Diponegoro; 2012. p. 44-8.

19. Sari N K. Perbedaan tekanan darah pasca anestesi spinal dengan pemberian preload dan tanpa pemberian preload $20 \mathrm{cc} / \mathrm{kgbb}$ ringer laktat . S.Ked [thesis]. Semarang: Universitas Diponegoro; 2012. p. 31-43. 